Article

\title{
Taming Distraction: The Second Screen Assemblage, Television and the Classroom
}

\author{
Markus Stauff \\ Media Studies Department, University of Amsterdam, 1012 XT, Amsterdam, The Netherlands; E-Mail: m.stauff@uva.nl
}

Submitted: 19 December 2015 | Accepted: 18 April 2016 | Published: 14 July 2016

\begin{abstract}
This article argues that television's resilience in the current media landscape can best be understood by analyzing its role in a broader quest to organize attention across different media. For quite a while, the mobile phone was considered to be a disturbance both for watching television and for classroom teaching. In recent years, however, strategies have been developed to turn the second screen's distractive potential into a source for intensified, personalized and social attention. This has consequences for television's position in a multimedia assemblage: television's alleged specificities (e.g. liveness) become mouldable features, which are selectively applied to guide the attention of users across different devices and platforms. Television does not end, but some of its traditional features do only persist because of its strategic complementarity with other media; others are re-adapted by new technologies thereby spreading televisual modes of attention across multiple screens. The article delineates the historical development of simultaneous media use as a 'problematization' - from alternating (and competitive) media use to multitasking and finally complementary use of different media. Additionally, it shows how similar strategies of managing attention are applied in the 'digital classroom'. While deliberately avoiding to pin down, what television is, the analysis of the problem of attention allows for tracing how old and new media features are constantly reshuffled. This article combines three arguments: (1) the second screen is conceived of as both a danger to attention and a tool to manage attention. (2) To organize attention, the second screen assemblage modulates the specific qualities of television and all the other devices involved. (3) While being a fragile and often inconsistent assemblage, the second screen spreads its dynamics - and especially the problem of attention-far beyond television, e.g. into the realm of teaching.
\end{abstract}

\section{Keywords}

assemblage; economy of attention; e-learning; liveness; second screen; television

\section{Issue}

This article is part of the issue "(Not Yet) the End of Television", edited by Milly Buonanno (University of Roma "La Sapienza", Italy).

(C) 2016 by the author; licensee Cogitatio (Lisbon, Portugal). This article is licensed under a Creative Commons Attribution 4.0 International License (CC BY).

\section{Introduction}

Television, like all media today, has become one of many possible objects of attention in a layered assemblage of platforms and devices. Especially the entanglement of mobile devices into television practiceswhat I will call second screen assemblages-organizes attention across several media, not least through harvesting, modulating, and combining the specific forms of attention characterizing different devices or different forms of content. Television's resilience in the current media landscape, I want to argue, can best be de- scribed with respect to a broader 'problem of attention'. The increasing interrelation between television and other media, on the one hand, provokes new ways of thinking about and dealing with attention; the strategies to create, organize and harvest attention, on the other hand, shape the media assemblage and grant particular, and often transitional, functions to one or the other device or cultural form. Television does not end, but its traditional features are re-adapted by new technologies thereby spreading televisual modes of attention across multiple screens.

The main aim of this article therefore is not to de- 
scribe the details of actual existing applications or forms of use but to analyze the 'problematizations' (Castel, 1994; Deacon, 2000) of attention: what are the conceptual and actual re-definitions of attention emerging across popular, industrial and academic debates? What strategies and instruments are imagined and realized to deal with attention (and distraction)? What happens to television's traditional modes of attention and how do other devices and practices appropriate them? While deliberately avoiding the attempt to pin down what television is and what it will become, such an approach allows for tracing how old and new features are constantly reshuffled. Thereby it also touches on more general media theoretical questions: is it still possible-and does it still make sense-to distinguish individual media? Can we actually identify affordances specific to one medium? Some traditional temporal characteristics of television-e.g. flow or liveness-are partly re-animated and transformed in a cross-media landscape, but they also get partly dissociated from television. This makes it increasingly difficult to isolate a particular medium in order to describe its features and affordances. This article focuses on the question of attention to show how television's loss of familiarity is negotiated. 'Problematizations' react to uncertainty and develop 'the conditions in which possible responses can be given' (Foucault, 1997, p. 118). Analyzing debates and strategies (instead of a given medium) also allows us to see the extent to which television shares dynamics with other media practices. The second screen use in teaching for example, which doesn't include TV-sets or TV-programs, shows interesting similarities with television's second screen assemblage and thereby delivers insights into the broader interdependencies of the medium's current developments.

In the following I will focus on the emergence of the second screen to analyze how television got integrated in a cross-media assemblage that appropriates the medium's features as strategies among others to create and modulate attention. The growing research on the topic has mainly discussed how the second screen gets applied to integrate the more volatile use of mobile devices into the commercial strategies of the media industry (Lee \& Andrejevic, 2014; Tussey, 2014) and how it creates moments of participation and liveness (van Es, 2015; Walsh, 2014). Other research has focused on the social circumstances of second screen use (Wilson, 2016), the spatial transformation of TV (Stauff, 2015), on the changing relationships between producers and audiences (Bennett, 2012), and on the second screen's potential to heighten a sense of citizenship (Selva, 2016). Dan Hassoun's rich work has shown how the second screen is policed in the cinema (Hassoun, 2016) and in the classroom (Hassoun, 2015) and how it relates to broader concerns of simultaneous media use (Hassoun, 2012, 2014). Adding to this growing body of research I want to focus more on the conceptual and theoretical implications of the second screen. First I will show how 'complementary simultaneous media use' (Nee \& Dozier, 2015) became a plausible and manageable concept for the media industry. To achieve that, the different media's competition for attention and the simultaneous but unrelated use of several media (multitasking) had to be transformed into an assemblage that frames and tames attention. Second, I will use the example of liveness to show how television's alleged specificities are re-articulated and dispersed in that process-television rather becomes an occasional phenomenon than an individual medium. Finally, to show how television's transformation is entangled with a broader problematization of attention, I will extend the analysis to the field of teaching. Second screens are used in classrooms too to transform distraction into attention and the respective debates and strategies are insightful for understanding television's changing role in the cross-media assemblage.

\section{TV, Digital Media and the Zero-Sum Game of Attention}

Already before the rise of mass media like film and television, media technologies have aimed to modify, increase, and manage attention (Crary, 2001, 2014). Early on in this development, attention became reconceived as a complex and temporal process: distraction was now considered to be a constitutive part of an unavoidably distributed form of attention (Löffler, $2013,2014)$. This ambivalent relationship between attention and distraction got thereby established as one of the key concepts for the evaluation and application of new media technologies, especially in the context of industrialization and urbanization since the mid-19 ${ }^{\text {th }}$ century: what looks like the danger of distraction at one moment, becomes a new form of attention at the next. The contemporary multiplication of screens and gadgets, and especially the second screen-assemblage, can be considered as yet another decisive turning point in this history. The simultaneous use of different media with allegedly each specific forms of temporality intensifies both the menace of constant distraction and the promise of micro-managed attention.

The dangers of mobile screens' distractive potential are most dramatically expressed in the context of driving. Many countries have enacted laws prohibiting the use of mobile phones while driving a car. Additionally, public awareness campaigns - with taglines such as 'don't text and drive' or 'keep your eyes on the road'often sponsored by car manufacturers, aim to convince drivers not to be tempted to use their smartphones behind the wheel (e.g. "KeepYourEyesontheRoad.org.au," n.d.). Interestingly, a spot by car manufacturer VW fuses movie-going and driving: in a Hong Kong cinema, watching a film shot from the 
point-of-view of a driver, audience members all simultaneously receive a text message. Grabbing their phones to read the message, they miss the moment in the movie where the driver has an accident-looking up from their mobile screens, all they see is a shattered windshield on the big screen (adsoftheworldvideos, 2014). For driving as for movie-going, the mobile screen is depicted as a problem of distractionannoying at best, life threatening at worst.

While in fact many cinemas (or concert halls and theatre venues) do ask the audience to switch off their mobile devices before the start of the show (Hassoun, 2016), the case of multiple-screen use here has become much more ambivalent (and therefore productive) in recent years. Movies, theatre shows, and particularly television have begun to harness rather than ban the second screen-both to safeguard attention and to augment the experience. ${ }^{1}$ Tellingly, one of television's early second screen apps was called GetGlue as if promising that the second screen intensifies rather than undermines the viewer's attachment to the screen. Before 'complementary simultaneous media use' (Nee \& Dozier, 2015, p. 2) could become a plausible concept, however, the alternating use of media and the mere accidental simultaneous use (multitasking) had to be molded into a densely interrelated and manageable assemblage.

Compared to cinema, television is notorious for affording a less focused but also more ambivalent mode of perception. Partly passively following the 'single irresponsible flow of images and feelings' (Williams, 1990, p. 92), partly distractedly zapping between channels or between watching television and other domestic activities, the viewer's attitude towards TV has been described as working through 'glance' rather than cinema's 'gaze' (e.g. Ellis, 1992). Ever since television's beginnings, people have read the newspaper, cooked dinner, or played board games while watching (or at least sometimes glancing at) a television. ${ }^{2}$ Applying a somewhat more extended concept of media, the distraction of the second screen is thus nothing new. The industry constantly had to develop strategies to guarantee that the audience would at least pay attention to the commercials; the soundtrack of television - which can more easily be followed while doing other thingswas e.g. adapted to the need to 'call the intermittent spectator back to the set' (Altman, 1986, p. 50). Characteristically, the growing presence of digital media in

\footnotetext{
${ }^{1}$ Disney brought a re-vamped, second screen-version of some of its movies to the cinemas (Lawler, 2013); examples of second screen use in the opera are described by Kozinn (2014).

2 This goes back to Raymond Williams' analysis of how television's flow fits into the broader development of 'mobile privatization' and was especially highlighted in the early feminist approaches to TV Studies, e.g. Modleski (1983). An extensive literature review is offered by Hassoun (2014).
}

the domestic space during the 1990s was also considered both as a heightened danger to the already fragile attention levels the TV industry had to contend with and as an opportunity for more attentive TVconsumption.

On the one hand, it was far from clear in the 1990s whether television would survive the competition of digital media. The success of the personal computer and the first signs of the Internet's popularization were conceived of as instigating a 'war for eyeballs' ${ }^{3}$ - the established TV industry and the growing IT industry fighting over consumers' attention. Until this day, the more radical proponents of the debate still consider television-notwithstanding all its digital transformations-a waste of time, and argue for its replacement by new media. In a blog post from 2008, for instance, new media scholar and consultant Clay Shirky calculated all the hours spent watching sitcoms and argued that this constitutes a waste of cognitive surplus that would be much better spent on writing blogs and editing Wikipedia entries, concluding: 'it's better to do something than to do nothing.' (Shirky, 2008) The underlying assumptions of such a dichotomy between television and new media are (1) that each medium is characterized by its specific form of attention and (2) that media consumption is a zero-sum game: the time spent with digital media will be taken out of the time previously spent watching television.

On the other hand, however, it became a plausible invocation to use new technologies to improve television's attention management. Already in 1986, a commercial for a (pre-digital) Panasonic VCR showed that a ringing phone is much less of an unwelcome distraction (and rather a temporary switch of attention) if you can voluntarily pause your viewing and continue where you stopped right after the call (mycommercials, 2007). This and similar situations (e.g. a decisive moment in a sports game while the postman rings or a dog that desperately asks to be taken out) have become staples of DVR advertising, promising that the upgraded medium can cope with the distractions of other media and life itself (Stauff, 2005, p. 215f). Increasingly, the inattentive consumption of scheduled (and thus not viewer-determined) television was portrayed as a waste of time (as in Shirky's blog); yet the new, digitized forms of TV (video on demand, digital video recorders, streaming services) promised to "'rationalize"' the act of watching television' (Dawson, 2014, p. 223). They allow for organizing the amount, time, and speed of reception and thereby for adapting television more closely to the patterns of a flexible, neoliberal work- and lifestyle (Dawson, 2014). Television and its multiple supplements thus got entangled with the 'attention economy', which re-introduced scarcity to the infor-

3 In 1996, Andy Grove, then president of chip producer Intel, introduced this notion (Grove, 1996). 
mation economy's apparent abundance in the 1990s (Terranova, 2012).

The second screen assemblage partly builds on this promise of more flexible use of television. Yet is also epitomizes a new concept of the interrelation between television and new media, namely increasing saturation instead of competition or efficiency (Greer \& Ferguson, 2015). Attention is now conceived of as something that can be spread (and can be managed to spread) across different media, which are establishing a veritable 'attention ecology' (Pettman, 2016). This implies that quite different modes of attention become combined, which also dissolves the idea that each medium is characterized by one specific mode of attention.

\section{Simultaneous Media Use: From Multitasking to Second Screen Assemblage}

It was in the late 1990s and early 2000s that the productive interrelations between different media were discovered as well as manufactured-first in the form of alternating and only later in the form of simultaneous media use. A telling anecdote of accidental discovery springs from the Big Brother brand. The first season of the reality show in 1999 already made innovative use of new media and allowed the audience to follow online live streams 24/7. The producer and co-inventor of the program, Paul Römer, however, revealed that in the beginning his team was wary of 'giving away' the most spectacular scenes online. In fact, they had a red button that could prevent specific juicy situations from live streaming, based on the assumption that otherwise no one would watch the daily summaries screening every night on TV. When quite early on a somewhat lurid interaction between participants was livestreamed by accident, the ratings of the evening show were very high, contrary to all expectations. The internet turned out not to act as a competitor or mere supplement, but as a teaser for watching more TV. ${ }^{4}$ The manufacturing of such productive interrelations between television and new media got traction with 'second shift aesthetics' (Caldwell, 2003) and 'overflow'strategies (Brooker, 2001), as the television industry tried to get a grip on the time users spend with media

\footnotetext{
${ }^{4}$ Paul Römer told this anecdote during a guest lecture at the University of Amsterdam's Media Studies department on 7 January 2015. Early research on the BBC version of Big Brother argues that there was no strong interrelation between internet use and watching the show on TV (Hill, 2002). More generally, Big Brother is considered to be a turning point in cross-media relationships: 'while interactive websites, phone services, texting and email were initially seen as supplementary media forms attached to pre-existing television programmes, in Big Brother it can be argued that the programme shifts from being the centre of a media ensemble to being one component in a wider mediascape whose title becomes a familiar brand.' (Bignell, 2005, p. 146)
}

other than television by offering online content that is related to (and refers back to) television shows.

The second screen undermines and complicates these forms of cross-media flow since it transforms the alternation between different media into simultaneity. To achieve this, the habit of multitasking - the simultaneous but unconnected use of different media-has to be continuously transformed into the complementary use of distinct media infrastructures and devices. This is very much where television at the moment overlaps with broader problematizations of media culture: the specificities of media have to be arranged into an assemblage that allows for interconnection and interdependency, translating the always menacing threat of distraction into intensified attention.

At least since the start of the $21^{\text {st }}$ century, multitasking has become one of the predominant ideas to conceptualize the problem of attention in a heterogeneous media landscape (Hassoun, 2012). For some, media-supported multitasking promises to equip humans with new powers-a scenario for which depictions of octopus-like humans managing different tasks and several media with their eight arms has become the corresponding 'meme' (Rieger, 2012). More often, however, the multiplication of media and the 'process of context switching' (Ellis, Daniels, \& Jauregui, 2010), characterizing their simultaneous use, is supposed to undermine any longer-term or in-depth attention. At times, these concerns even provoke 'moral panics' around (especially children's) capacity to achieve and to have intense social, face-to-face communication (Bennett, Maton, \& Kervin, 2008; Cellan-Jones, 2010). More generally, the worries and promises around multitasking systematically interrelate the reflection on the limits of human capabilities with the (quantifiable) analysis of technological capacities and the discussion of appropriate application of different media (Rieger, 2012 , p. 16). Multitasking questions the quantity as well as the intensity of attention received by any single medium or individual cultural product, thereby also problematizing the specificities of media. With the evolving second screen assemblage, the much older concerns about multitasking while watching television could be translated into systematic industrial strategies.

In workplace ergonomics, multiple monitors are considered supportive to multitasking, since switching from one program (or task) to another no longer means that the first program (or task) disappears from sight (Manjoo, 2009). Such a multiplication of screens is aptly satirized in David Eggers' novel The Circle, in which the protagonist, who just got a job at a fictional new-media company, gets a new screen on her desk for each new task she is responsible for. Her desk becomes a veritable dashboard constantly reminding her of the parallel processes she is supposed to optimize (Eggers, 2014).

Until around 2007, the term 'second screen' was 
most often used in such specialized contexts, e.g. for the use of an additional computer monitor in desktop publishing. Since then, however, 'second screen' has started to signify the awkward and hybrid combination of considerably different kinds of screens, especially the screen of a domestic TV set with a mobile screen, thereby also combining linear and pre-structured content on one screen with individually accessible, 'interactive' forms on the other. Of course, the second screen might mainly be used to keep busy with other things while watching television and thus to multitask: answering emails, playing games, sorting photographs etc. As such, it constitutes a threat to the TV industry since people are thought to be more likely to pick up their second screens during commercial breaks (just as VCR and the DVR were used to skip or fast-forward through commercials).

Yet viewers also take advantage of their second screens to do TV-related things: searching for additional information, starting online conversation about a show, etc. (Nee \& Dozier, 2015) The industry, therefore, now envisions the second screen as a tool capable of transforming multitasking into a densely interrelated assemblage of devices and practices, and thus into a unified-if not necessarily coherent-experience. 'Unlike previous forms of "inattention", ancillary screens are seen as increasing cumulative exposure to media messages rather than detracting from them.' (Hassoun, 2014, p. 276)

As was the case with the alternating use of television and online media in the Big Brother 'discovery' relayed above, the possibility of a mutual intensification of simultaneous media use provides its own eyeopening anecdotes. One of the many telling examples for the interlocking of television and social media can be found in the Super Bowl of February 2013. The match was interrupted by a power outage shortly after the start of its second half and did not resume for more than half an hour. Since one team was already far in the lead when the game was interrupted, broadcasters worried that people would stop watching. Quite to the contrary, however, many new viewers learned about the unexpected development on social media, switched on their television sets, and shared pictures, jokes, and opinions online (Carter, 2013). It is now broadly understood that social-media conversation can direct attention towards television and television shows, and television has, in fact, become one of the most prominent topics of social media 'buzz'. This surely impacts the experience of watching television; a recent empirical study finds, e.g., that using a second screen while watching television adds to the 'perception among audience members that they had gained incidental knowledge.' (Nee \& Dozier, 2015)

The complementary use of media technologies modulates the divided and unstable attention that characterizes multitasking into a highly flexible, yet structured form of attention organized around a central topic or event, and framed and tamed by the centripetal dynamics of technical, textual, social strategies. Hashtags, specialized second screen apps, 'appointment television', and other means offer distractions to stretch and heighten attention (as will be discussed further down, this is also described as 'continuous partial attention'). If transmedia storytelling has become one of the core strategies to organize attention across alternating media use (Jenkins, 2010), 'liveness' has turned out to be one of the most relevant strategies to transform multitasking into a structured assemblage of different media and different modes of attention. It thereby also is a valuable concept to discuss the persistence and transformation of key features of television in the transforming media landscape.

\section{Second Screen-Liveness and The Non-Specificity of Attention}

Ironically, media technologies and media practices that were introduced as an explicit challenge (if not alternative) to television's basic temporal characteristics (scheduling, liveness, flow), now seem to salvage and emphasize television's liveness, which-historicallyhad seemed to be in decline due to recording, ondemand, and streaming technologies. Moreover, the second screen creates its own, modulated forms of liveness for different kinds of shows to guarantee heightened attention. At first sight, big live eventsfrom presidential addresses to sports events and natural catastrophes-quite simply combine two things: (1) they 'glue' people to their televisions and produce shared, synchronized, and focused attention, even in the era of 'whenever you want, where you want'; and (2) they simultaneously provide reasons and topics for conversations, and guarantee that others (either people one knows or perfect strangers) are watching the same show at the same time and thus are addressable in online communication.

The connection between liveness and attention is not a simple given, though. Instead, it is manufactured by the combination of multiple strategies involving different media. Liveness, as a substantial body of research has shown, always was a highly ambivalent, strategic, and partly ideological aspect of television. It comprises (and selectively highlights) the technical live transmission, the spontaneity of displayed behaviour, or the uninterrupted flow of images from heterogeneous locations (e.g. Caldwell, 2000; Feuer, 1983; White, 2004). In television history more generally, what appears to be a specific quality of the medium got continually re-defined in the assemblage of many different media. The consequences of video technology, first in production and later in reception, with the emergence of 'live on tape' or 'tape delayed'-events are proof of that. 
Social media intervene in this strategic field, taking advantage of, but also transforming, the multiple aspects of liveness. Television-related live-chatting is one of the key activities contributing to the commercial value of social media, especially Twitter (Walsh, 2014, p. 12). Social media conversations in turn equip even traditionally scheduled shows with a certain temporal urgency: while you can record a show to watch it at a later time, you cannot record and tape-delay the conversation accompanying the show on social media.

'Social TV is the industry's latest response to the challenges of the digital era, as channel proliferation and audience control over television consumption have eroded the viewership of network broadcasts. It encourages viewers to tune in to episodes as they air-rather than later when they can choose to skip the advertisements-and to strengthen audience engagement through participation.' (van Es, 2015, p. 2)

Online communication, thus, is not just a productive side effect of live events, it contributes to, and modifies, television's liveness and the respective attention, e.g. through creating and 'reaggregating' a mass audience (Lee \& Andrejevic, 2014).

The TV industry strategically boosts the 'eventfulness' of its programming with competitions and confrontations to provide repeated incentives for online discussion. Curated forms of participation, such as the possibility to vote or comment, entangle the immediacy of web communication with television's many forms of liveness (Ytreberg, 2009). Streaming services like Netflix or Amazon offer a non-scheduled and non-live mode of distribution that affords temporally flexible ways of (binge-) watching. Since such an individualized form of reception makes synchronization with social media difficult (not least because of possible spoilers for the viewers who started somewhat later), second screen use has to be carefully crafted. Netflix organized a 'live Twitter Q\&A' with the cast of Orange is the New Black (Edelsburg, 2013)..$^{5}$ And for another Netflix show, House of Cards, the second screen app Beamly promised to offer 'a TV room for each episode' (Dredge, 2014), that is, a space for conversation on one episode, independent from the moment of watching it, thereby compartmentalizing liveness even further. More generally, research has shown that watching TV shows via streaming 'distributes the articulated social space through time (diachronic) over a longer period than a single temporal (synchronic) event.' (Pittman \& Tefertiller, 2015) Even if most of the audience might contin-

\footnotetext{
5 Partly due to contractual obligations, Netflix also releases some shows weekly, thereby undermining a too-clearcut distinction between ('traditional') scheduled TV and nonscheduled streaming services (Arnold, 2015).
}

ue with their own idiosyncratic forms of second screen use and most of the industrial strategies are short-lived they nevertheless feed into the problematizations of attention.

In a second screen assemblage, liveness is used to suture (to use a metaphor from film theory ${ }^{6}$ ) the gap between previously opposed forms of temporalitymost explicitly, of course, the scheduled temporality of what is now called 'appointment television' and the more flexible 'always-on' temporality of social and mobile media, which replaces the scheduled liveness of TV with 'online liveness' and 'group liveness' (Couldry, 2004). TV producers harvest the temporalities of the buoyant social-media communication to strategically equip all kinds of TV content with the attention-binding features of liveness. The second screen additionally aims to combine what Jenkins, Ford and Green (2013) sharply distinguish as 'stickiness' vs. 'spreadability'simultaneous attention of a mass audience and nonsynchronized attention of successive 'sharing'. It thereby transforms the parallel existence of different modes of perception and especially the threat of multitasking into an assemblage that promises to frame and tame the interplay of distraction and attention.

This is clearly not the end of television, since at least some aspects of the medium are used and intensified by 'new media'. Nevertheless, the example of the second screen also shows that television has-like any other individual medium-become part of a broader assemblage that selectively appropriates, modulates and re-articulates features of different media to tackle the problem of attention. Here, television's current development provokes some more general media theoretical questions concerning the specific affordances of different media. While media assemblages are often conceived of as 'stabilized systems made of elements, actors, and processes that are shaped and "fixed" to "fit" together...in order to produce a culturally stable form of communication' (Langlois, 2012, p. 93), the second screen's mixed and changing strategies to organize attention seem rather to create continuously new relations between textual and technical elements familiar from traditional television and emerging from the social-media context (Rizzo, 2015).

The social-media platforms Twitter and Facebook in particular were quite explicitly established as modes of social communication completely different from television. Both platforms, however, have become seminal pillars of the second screen assemblage. Similarly, mobile media, tablets and phones, are characterized by their ability to disconnect the access to content from a pre-determined place (the living room) and from the rigid schedules of television. Nevertheless, in the past few years media development has been shaped by the highly productive overlap between certain aspects and

${ }^{6}$ For the debate in film studies, e.g. Miller (1977). 
features of social media with certain aspects and features of television. The characteristics that are allegedly specific to individual media have in the process also become highly ambivalent and interdependent.

The individual devices and platforms contributing to the assemblage can be analyzed with respect to each of their specific temporal affordances (e.g. Weltevrede, Helmond, \& Gerlitz, 2014). Looked at separately, each has a specific pace of incoming information, of refreshing, and of trending, and therefore each requires different modes of attention. Liveness, as I have shown, persists as a strategy to manufacture productive interconnections and synchronization across devicesthereby affecting and modulating their characteristic temporalities and modes of attention. It "has to be understood in the context of the entire multiplatform and interactive mediascape that it is part of, and evolving around, as well as in relation to the dynamics between devices, platforms and content providers' (Sørensen, 2016 , p. 396). Additionally, in a cross-media ensemble, liveness eventually does not so much synchronize but rather strategically 'hypermodulate' attention, producing micro-delays, stuttering interrelations and 'deliberate dissonance' (Pettman, 2016).

The second screen assemblage undermines any clear-cut identification of one medium with one mode of attention. It frames and tames attention by combining media-event liveness with group liveness, and stickiness with spreadability. It thereby also combines the two modes of attention, identified by Katherine Hayles in comparing print-dominated and online culturedeep attention (characteristic of the practice of 'close reading') and hyper attention: 'hyper attention is characterized by preference for multiple information streams, flexibility in rapidly switching between information streams, sensitivity to environmental stimuli, and a low threshold for boredom, typified, for example, by a video game player.' (Hayles, 2012) The second screen, on the one hand, does fit most of the characteristics listed here. On the other hand, the abstract classification of 'hyper attention' risks obscuring the fact that the 'multiple information streams' only get connected because they offer different forms of (manipulating) attention, including (at least the promise of) deep attention. ${ }^{7}$

After all, the second screen assemblage gets explicitly introduced as a tool to manage (different forms of) attention in social situations. An instructional video for Google's Chromecast, a small device that enables an easy connection between tablets or smartphones and a TV set, can be taken as quite typical here. It shows a young man sitting down on a couch, where a young woman is already sitting, taking notes in a booklet with

\footnotetext{
7 While focusing on individual choice, access, and social communication, commercials for second screen use do regularly include images of immersion, absorption, and focused attention.
}

a pencil; he touches her, she briefly looks up, but continues focusing on her booklet. He activates Google Chromecast and opens a photo app on his smartphone to display the pictures on the big TV screen. When he choses a short video clip showing the young woman sitting on a kitchen counter throwing nuts in the air to catch them with her mouth, he finally gets her attention and they start teasing each other (Google Chrome, 2014). Well beyond TV-related liveness, the second screen assembles different forms of attention in competitive interrelation and along the way allows for the redefinition of a social situation by determining a (momentary) shared focus of perception.

Most of the strategies discussed so far can be ascribed to the television industry's endeavours to tame the disruptive potential of mobile media by connecting them to the entertainment industry's more traditional and well-proven commercial strategies (Tussey, 2014). The second screen's entanglement with the problem of attention, however, is feared and harnessed in other contexts as well. In this sense, the second screen can be considered a 'dispositif' or an 'assemblage' that inserts its particular rationalities and problematizations into a variety of media and into different social practices-including the practices of teaching and lecturing, as I will discuss in the remainder of this article. The analysis of television's transformation might benefit from such a comparison since it allows us to see more clearly, how particular strategies organize a crossmedia assemblage partly independent of individual devices. The second screen, one could argue, imports features and concerns of television-or problematizations related to the current transformation of television-to circumstances in which no TV set and no broadcaster is present.

\section{Managing Attention in the Classroom}

If television's current transformation is being shaped by the way it is integrated into a media assemblage that organizes attention and distraction across several devices and platforms, much the same can be said about transformations in teaching and lecturing. In education, the question of attention is as hot an issue as it is in advertising and the entertainment industry, and here too the emergence of ever new assemblages is organized by the alleged potentials of different media in producing attention/distraction.

For centuries, pedagogy has been struggling with the problem of distracted pupils, and as early as the 1780s the Swiss education reformer Johann Heinrich Pestalozzi, in the context of a more general reassessment of distraction, 'assigned a value to distraction as a pedagogical tool. He recommended giving pupils two tasks simultaneously so that they have to distribute their attention.' (Löffler, 2013, p. 14; see also Löffler, 2014, p. 60f). Regularly, media have played a promi- 
nent role in such pedagogical efforts to re-organize and intensify the attention of learners. In this context, media were often tweaked and used in alternative forms, thereby adding features and characteristics to media that were otherwise overlooked (for film see e.g. Hediger \& Vonderau, 2009). Even television, so often considered detrimental to all forms of rational learning (most prominently in Postman, 1986) was praised and appropriated for its potential to improve teaching (e.g. Keilbach \& Stauff, 2013). No wonder then that the second screen's problem of attention is intensely articulated in the field of education: the second screen is both banned from class for its distracting potential and intensely appropriated to frame and tame the unavoidable allure of its own and other distractions-not to mention adapting the classroom to the world and habits of contemporary students. Comparing the application of the second screen in education with its application in the field of television highlights the extent to which the problem of attention structures the emergence of media assemblages and thereby changes the role and function of individual devices.

Media were accused of having a detrimental effect on children's capacity to learn long before those media entered the classroom-television was considered especially harmful: ${ }^{8}$ If children were twitchy on Mondays, this could easily be ascribed to their excessive TV consumption during the weekend. ${ }^{9}$ More generally, TV is criticized for taking time from other more beneficial activities-reading, exercising, etc. These concerns only intensify once screens are brought into the classroom via the rise of mobile media and compete simultaneously with the teacher for the students' attention. Since individual media use in the classroom has become ubiquitous and nearly unavoidable (Hassoun, 2015), the classroom itself becomes a field of competing strategies to foster attention. Mirroring the transition from alternating to simultaneous media use discussed earlier, the discussion in didactics also seeks to establish a media assemblage that could tame multitasking and intensify the overall attention.

First of all, individual media in the classroom are considered a source of distraction from the 'main screen' - the teacher and his/her blackboard, whiteboard, or presentation screen. The Dutch center of expertise for media literacy, mediawijzer, recently published a survey showing that about $50 \%$ of the pupils

${ }^{8}$ For an overview of several issues, see e.g. the University of Michigan Health System's page on TV: http://www.med. umich.edu/yourchild/topics/tv.htm; for an academic reversal that argues for TV's benefits for teaching in general, see Hartley (1999).

9 In Germany, this was often called the 'Monday syndrome' ('Montags-Syndrom'). In 2000, a newspaper article on the topic quoted a teacher stating that pupils behaved 'as if their central nervous system was short-circuited by television' (Struck, 2000). use their mobile phones during lessons for private matters-sending messages to friends, surreptitiously taking photographs and videos, checking social media, etc. (“Monitor Jeugd en Media 2015," 2015). A discussion paper from LSE's Centre for Economic Performance more dramatically argues that banning mobile phones from schools would equal a learning advantage of one extra week of teaching per year (Beland \& Murphy, 2015). Already in 2014, Clay Shirky (who has repeatedly been criticized as an 'Internet guru' (e.g. Morozov, 2011, p. 21)) surprised his audience with a blog post in which he laid out the reasons for banning laptops from his classroom: they do not only distract the attention of users, but also create a distracting atmosphere for students not using their gadgets (Shirky, 2014). Neurological and psychological research seems to corroborate these concerns, showing that students regularly overestimate their potential for multitasking (Weimer, 2012) and that extensive multitasking results in lower grades (Ellis et al., 2010). My interest doesn't lie in denying or even debating these insights. Rather, I want to discuss how these problematizations contribute to the emergence of a media assemblage in which quasitelevisual and new-media forms of communication are re-organized.

Eventually, for many, new media have become tools for getting and keeping the attention of the younger generation and methods are developed so that the attention that is unavoidably spent on new media can be redirected to teaching endeavors. More hesitant strategies-as for example outlined in a book with the telling title Teaching Naked (Bowen, 2012)still keep the classroom free from media but argue that media can and should be used to expand teaching (and attention to the objects of teaching) beyond the time and space of the classroom. In accordance with the imperative of 'lifelong learning', media create a 'teaching environment' or a 'teaching ecosystem' where teaching (similar to what HBO GO and similar initiatives promise for entertainment media) can be taken with you 'wherever you go' and 'whenever you have time' for it. ${ }^{10}$ The 'gamification' movement is likewise based on such an effort to carefully translate the detrimental potentials of media into productive strategies. One of the books introducing the topic argues that the attention given to, e.g., World of Warcraft could be redirected to more useful and beneficial things-

10 On Twist, the official blog of The Elearning Guild, program director David Kelly explains the concept of the learning ecosystem as follows: 'In today's digital world, a web of learning resources surrounds every individual. It's an environment wherein each resource connects to others, creating an overall structure in which all learning takes place. The learning ecosystem is the combination of technologies and support resources available to help individuals learn within an environment.' (Kelly, 2013). 
'harnessing the characteristics that make them [games] so engaging and applying them to other aspects of lives' (Penenberg, 2013, p. 11).

The less fearful proponents of the debate actually do urge the use of new media in the classroom simultaneously with, and in augmentation of, the teacherstudent relationship. The most pragmatic argument for this strategy is often that for the younger generation multitasking has become the norm (see Bennett et al., 2008 , for a critical perspective on this argument). Even if the multiple sources of information might distract from the main focus (i.e., the teacher), this is nevertheless considered the best strategy to keep students interested by at least fostering 'continuous partial attention' (Muir, 2012; Yardi, 2006)-a mode of attention that distinguishes itself from the worrisome multitasking since it is organized around one main focus but concedes (or incites) the constant scanning of the environment for additional information (Löffler, 2013, p. 17).

While chatting in the classroom might still be an annoyance, the mediated real-time conversation alongside a common activity (a lecture or a workshop) is considered beneficial for 'continuous partial attention', as such 'backchannel' communication purportedly transforms students (or 'the audience') from passive listeners into participants of an on-going discussion. Additionally, the 'conspicuous covertness' (Hassoun, 2015 , p. 1686) of students' private use of social media is overcome by harnessing this media use for the ends of learning. Schools and universities are advised to use social media to enhance the feeling of a learning community. Again in parallel to the recent developments in the TV industry, 'social' or 'community' are here defined in terms of conversation and interaction, rather than in terms of common listening or watching. ${ }^{11}$ In both cases this understanding of the social is inseparable from the assumption that social exchange keeps you more active and more attentive.

Quite similarly to the attention problem of commercial television, the teaching context provokes the emergence of strategies and specialized tools with the aim of managing the relation between the (potentially distracting) second screens and the designated main focus of attention. This ranges from low-tech arrangements (e.g. the common agreement on a 'cell phone etiquette' in the classroom [Nielsen \& Webb, 2011]), to highly specific technical tools offered by a veritable and thriving e-learning industry. The teachers' roles change in this context-they need to 'manage' the classroom and to monitor what the students are actually doing with their phone, thereby transforming 'the classroom dynamic from lecturing at the front of the room to having no traditional front of the classroom at all' (Graham, n.d.).

11 The limitations of this concept of the social are e.g. outlined by Lacey (2013) and Peters (2005).
The tensions that have to be navigated here become especially clear with respect to backchannel communication, that is, the use of the second screen for online conversation 'as a secondary or background complement to an existing frontchannel, which may consist of a professor, teacher, speaker, or lecturer' (Yardi, 2006, p. 852). The backchannel is always threatening to take over attention from the main focus point and thereby pulling students back into the problematic mode of multitasking - either by going off-topic or by focusing on aspects of the learning situation that do not belong to the content. Exchange that is supposed to augment the frontchannel slips into 'miscellaneous conversations' (Du, Rosson, \& Carroll, 2012, p. 135), snarking about the manner of presentation, the haircut of the presenter, etc. Often, such '[a]ttention issues [are] mentioned in the backchannel itself' (McCarthy \& boyd, 2005, p. 1643).

Extending my selection of examples beyond the classroom to conferences, I want to point to socialmedia researcher danah boyd's report of a case from her own experience as a presenter. While she gave a talk during the WEB 2.0 Expo in 2009, the attention in the room was overtaken by the backchannel communication where some people commented on boyd's style of presentation. Reflecting on the experience in a blog post, she states that a Twitter stream 'forces the audience to pay attention [to] the backchannel. So even audience members who want to focus on the content get distracted' (boyd, 2009a). Quite similarly to TV shows which are made more eventful in reaction to second screen use, the conference talk (which, ironically, compared broadcast and online modes of attention [boyd 2009b]) needs to adapt to compete (or interrelate) with the attention-sucking backchannel, according to boyd:

'Had I known about the Twitter stream, I would've given a more pop-y talk that would've bored anyone who has heard me speak before and provided maybe 3-4 nuggets of information for folks to chew on. It would've been funny and quotable but it wouldn't have been content-wise memorable.' (boyd, 2009a)

Media use that is supposed to be augmenting an already established communication situation can thus provoke changes in the content and form of teaching, so that multitasking gets modulated into continual partial attention and actually heightens instead of damages the attention. An advice book on backchannel communication has an entire chapter titled 'Making your ideas Twitter-friendly' (Atkinson, 2009). Interestingly, another suggestion for disciplining the backchannel is to display it for everybody. Snarking is thus avoided through a form of public monitoring (Yardi, 2006, p. 855). Additionally, the presenter is expected to have an eye on the back- 
channel as well-though some authors also warn that the audience might not like it when a speaker pays more attention to backchannel than to the content of the actual presentation (Atkinson, 2009, p. 25).

This tricky balance is the main rationale behind the development and the promotion of special appliances that frame and tame distraction or multitasking similarly to the second screen apps of television: quizzes students can take part in during lectures, the results of which can be immediately integrated into the slides of the teachers, etc. ${ }^{12}$ As if a lecture would not be sufficiently 'live', the Polleverywhere app, for instance, aims to integrate a 'moment of excitement' into lectures when 'live results flash on the wall'; a professor's testimonial on their webpage claims: 'Poll Everywhere helps me keep my overworked residents awake when I talk!' For conferences and business meetings, the 'event software provider' Lintelus presented its second screen technologies as the 'best tools for engaging the audience'. They are supposed to transform 'a simple presentation' into 'an attention-grabbing interactive experience for all' by 'personalizing the experience for every attendee' and allowing the participants to 'chat with other participants'. ${ }^{13}$

We might very well doubt whether chatting with other conference participants during a talk does in fact connect presenter and audiences 'like never before' (as is also claimed). Significantly, however, the debate takes for granted that attention for different media is no longer considered a zero-sum game and that only the mix of different media creates liveness, collectively shared focus and continuing engagement. As with television's second screen assemblage, the interconnection of different forms of perception (e.g. 'passively' listening, 'actively' texting) promises to harvest different modes of attention and thereby changes the very temporality of the involved activities and technologies. In teaching, as in watching television, the 'specificities' of different media are only invoked and addressed to be modulated in the dynamic assemblage that is constantly re-arranged, distributing attention across the multiple screens. The function of teacher / lecturer is not just augmented through the additional media, but it becomes more volatile and strategic-being the main attraction for some moments while functioning as mere inducer and organizer of further activities at others.

\footnotetext{
12 E-learning company socrative promises: 'through the use of real time questioning, instant result aggregation and visualization, teachers can gauge the whole class' current level of understanding. Socrative saves teachers time so the class can further collaborate, discuss, extend and grow as a community of learners' ("Socrative," n.d.).

13 The quotes where retrieved from the webpage of Lintelus (lintelus.com), which is no longer accessible; an instructional video with a similar rhetoric is still available on (Lintelus, 2014).
}

\section{Conclusion}

In teaching as in television, what was previously considered to be a dominant center of collective attention is very much re-organized in a multiple-media landscape. Interestingly, this past dominance is questioned and supported by new media which appear as competitors but quickly become supplements-partly reanimating established features, partly creating new ones. The assemblage, television (and teaching) becomes part of, seems neither defined by the affordances of each of the involved devices and platforms, nor by the diagram of their connections and interrelations. It is rather the problematizations that are articulated through the transformation of this assemblage that endow it with particular functions and dynamics; one and the same platform or device-e.g. what we used to call television-at times is strategically harnessed for some of its established characteristics but at other moments becomes transformed beyond recognition. This is not yet the end of television, indeed; some of its traditional features gain a new dynamic in the complementary relationship with new technologies. While it becomes more and more difficult to point at one device or one mode of media use that clearly is television, the contemporary problematizations of the media assemblage re-adapt features that gain all their plausibility from the history and current transformations of television.

The endeavor to convert multitasking into simultaneous and interrelated (or 'continuous partial') attention is one of the dominant problematizations of contemporary media assemblages. The second screen's entanglement with the problem of attention continues a trend that goes back to at least the $19^{\text {th }}$ century: while technical media have long provoked concerns about human attention, they have simultaneously been appropriated to gauge and manage attention (and distraction) so that it can be harvested, sold, and exploited. It is hardly an exaggeration to state that without media, attention wouldn't exist-neither as epistemic object, nor as an everyday concern of common people. While people might have always paid attention (or not) to things happening, the 'imperative of a concentrated attentiveness' (Crary, 2001, p. 1) could only start shaping subjectivities when different media, each with a specific temporal structure, compete for attention at work places and in leisure time. Attention can thus best be conceived of as 'the contingent product of changing relations between individuals, collectivities, technological conditions, and social habits' (Read, 2014).

The increasing diversity and ubiquity of media forms and devices provoked by digital and mobile media is often described as a dynamic that divests each individual and society at large of the basic capability to self-determine when to pay attention and to what. Barbara Stafford claims that 'the proliferation of autopoietic devices and zombie media' (Stafford, 2009, p. 
289) takes the distinction between what matters and what doesn't out of our hands (or rather our minds); Giorgio Agamben states that no one captured by television or a cell phone can 'acquire a new subjectivity' (Agamben, 2009, p. 21). Jonathan Crary, in his aptly titled book 24/7, argues that television was an important step in adapting our attention and experience to capitalisms' 'uninterrupted operation of markets, information networks, and other systems.' (Crary, 2014, p. 9) With ever more media and their respective 'infinite cafeteria of solicitation and attraction perpetually available, 24/7 disables vision through processes of homogenization, redundancy, and acceleration.' (Crary, 2014, p. 33) While Crary does not discuss the second screen explicitly, it can easily be understood as one of the strategies of further intensification he hints at: '24/7 capitalism is not simply a continuous or sequential capture of attention, but also a dense layering of time, in which multiple operations or attractions can be attended to in near-simultaneity, regardless of where one is or whatever else one might be doing.' (Crary, 2014, p. 84)

With respect to the examples from the TV industry and from the context of teaching, I would however also like to highlight the heterogeneity and the fragility of the second screen's modes of attention. The different narrative forms of television each already allow their own specific combination of attention and distraction (Pape, 2014). The second screen additionally exemplifies that attention for a show or a lecture-and even more so attention 24/7-is at the moment considered to be best enabled by entangling different and competing temporalities. This can be understood as yet another overstraining of the individual's perceptual capabilities characterizing industrial capitalism and urban life since the $19^{\text {th }}$ century. It can, however, also be taken as another example of modernity's ambivalent constitution of attention, summarized by Crary himself (referring to Sigmund Freud's description of a public place in Rome): Instead of a seamless regime 'it will be a patchwork of fluctuating effects in which individuals and groups continually reconstitute themselveseither creatively or reactively' (Crary, 2001, p. 370). In a similar vein, Tiziana Terranova argues that new media's capture of attention (and, I would add, the second screen's combination of TV- and group-liveness) can ably develop new forms of social attention and 'trigger the emergence of a new collective organization' (Terranova, 2012, p. 12).

Additionally, I hope my analysis has shown that the second screen assemblage produces as many attention problems and tensions as it offers solutions. Attention, thus, is not something that media quite simply capture, manufacture, or manipulate; rather it is one of several problematizations that structure the assemblage of heterogeneous elements. The idea of the specific affordances of different media, on the one hand, is una- voidable for the management of attention. Television with its rich history of industrial and reformist strategies fighting the worrying distractive or time-wasting affordances of the medium still remains a major reference point here. On the other hand, the distribution of attention across devices and media forms has become one of the key concepts that allow for the entanglement of different media in an assemblage that modulates each of their characteristic qualities. Media studies should not focus on the unlimited capturing capabilities of the increasingly connected media machinery alone, but also on the wider cultural problems that are more articulated than solved by the ongoing transformation of the media assemblage. Here, television figures less as one medium that continues or ceases to exist than as a set of traditions, concerns and strategies that contributes to this transformation.

\section{Acknowledgments}

I am grateful to Florian Duijsens, Abe Geil, Karin van Es, and the anonymous reviewers for their thoughtful feedback on earlier versions of this article.

\section{Conflict of Interests}

The author declares no conflict of interests.

\section{References}

adsoftheworldvideos. (2014). Volkswagen: Eyes on the road. Retrieved from https://www.youtube.com/ watch? $\mathrm{v}=\mathrm{R} 22 \mathrm{WNkYKeo8}$

Agamben, G. (2009). "What is an apparatus?" and other essays. Stanford, CA: Stanford University Press.

Altman, R. (1986). Television sound. In T. Modleski (Ed.), Studies in entertainment: Critical approaches to mass culture (pp. 39-54). Bloomington: Indiana University Press.

Arnold, S. (2015, March 20). Scheduling television on post-television platforms. Retrieved from http://cst online.tv/scheduling-television-on-post-televisionplatforms

Atkinson, C. (2009). The backchannel: How audiences are using Twitter and social media and changing presentations forever (1st ed.). Berkeley, CA: New Riders.

Beland, L.-P., \& Murphy, R. (2015). IIl communication: Technology, distraction and student performance (CEP Discussion Papers No 1350 No. CEPDP1350). CEP. Retrieved from http://cep.lse.ac.uk/pubs/ download/dp1350.pdf

Bennett, L. (2012). Transformations through Twitter: The England riots, television viewership and negotiations of power through media convergence. Participations: The International Journal of Audience and Reception Studies, 9(2), 511-525.

Bennett, S., Maton, K., \& Kervin, L. (2008). The “digital 
natives" debate: A critical review of the evidence. British Journal of Educational Technology, 39(5), 775786. doi:10.1111/j.1467-8535.2007.00793.x

Bignell, J. (2005). Big brother: Reality TV in the twentyfirst century. Basingstoke: Palgrave Macmillan.

Bowen, J. A. (2012). Teaching naked: How moving technology out of your college classroom will improve student learning. NJ: John Wiley \& Sons.

boyd, d. (2009a, November 24). Spectacle at Web 2.0 Expo...from my perspective. Retrieved from http:// www.zephoria.org/thoughts/archives/2009/11/24/s pectacle_at_we.html

boyd, d. (2009b, September 17). Streams of Content, Limited Attention: The Flow of Information through Social Media. Retrieved May 3, 2016, from http:// www.danah.org/papers/talks/Web2Expo.html

Brooker, W. (2001). Living on Dawson's Creek: Teen viewers, cultural convergence, and television overflow. International Journal of Cultural Studies, 4(4), 456-472.

Caldwell, J. T. (2000). Live slippages: Performing and programming televisual liveness. In G. Hallenberger \& H. Schanze (Eds.), Live is life. Mediale Inszenierungen des Authentischen (pp. 21-46). Baden-Baden: Nomos.

Caldwell, J. T. (2003). Second shift media aesthetics: Programming, interactivity, and user flows. In A. Everett \& J. T. Caldwell (Eds.), New media. Theories and practices of digitextuality (pp. 127-144). London: Routledge.

Carter, B. (2013, February 4). Blackout Is a Boon for Super Bowl Ratings. Retrieved May 3, 2016, from http://mediadecoder.blogs.nytimes.com/2013/02/0 4/blackout-is-a-boon-for-super-bowl-ratings/

Castel, R. (1994). "Problematization" as a mode of reading history. In J. Goldstein (Ed.), Foucault and the writing of history (pp. 237-252). Oxford/Malden: Blackwell.

Cellan-Jones, R. (2010, August 19). A multi-tasking moral panic. $B B C$. Retrieved from http://www.bbc.co.uk/ blogs/thereporters/rorycellanjones/2010/08/a_multi -tasking_moral_panic.html

Couldry, N. (2004). Liveness, "reality," and the mediated habitus from television to the mobile phone. The Communication Review, 7(4), 353-361. doi:10.1080/ 10714420490886952

Crary, J. (2001). Suspensions of perception. Attention, spectacle, and modern culture. Cambridge, MA: MIT Press.

Crary, J. (2014). 24/7: Late capitalism and the ends of sleep. Brooklyn, NY: Verso.

Dawson, M. (2014). Rationalizing television in the USA: Neoliberalism, the attention economy and the digital video recorder. Screen, 55(2), 221-237. doi:10.1093/ screen/hju011

Deacon, R. (2000). Theory as practice: Foucault's concept of problematization. Telos, 2000(118), 127-142.
Dredge, S. (2014, April 14). Social TV app Zeebox relaunches as Beamly to lose "male geeky" image. The Guardian. Retrieved from https://www.theguardian. com/technology/2014/apr/14/zeebox-beamly-socialtv-app

Du, H., Rosson, M. B., \& Carroll, J. M. (2012). Communication patterns for a classroom public digital backchannel. In Proceedings of the 30th ACM International Conference on Design of Communication (pp. 127-136). NY: ACM. doi:10.1145/2379057.2379081

Edelsburg, N. (2013, July 19). Meet the cast of Netflix's "Orange is the New Black" during tonight's Twitter chat. Retrieved May 3, 2016, from http://www. adweek.com/lostremote/meet-the-cast-of-netflixsorange-is-the-new-black-during-tonights-twitterchat $/ 39255$

Eggers, D. (2014). The circle: A novel. London: Penguin Books.

Ellis, J. (1992). Visible fictions. Cinema-television-video. Revised edition. London: Routledge.

Ellis, Y., Daniels, B., \& Jauregui, A. (2010). The effect of multitasking on the grade performance of business students. Research in Higher Education Journal, 8, 1. Retrieved from http://www.aabri.com/manuscripts/ 10498.pdf

Feuer, J. (1983). The concept of live-television: Ontology as ideology. In E. A. Kaplan (Ed.), Regarding television: Critical approaches-An anthology (pp. 12-22). Los Angeles: American Film Institute.

Foucault, M. (1997). Polemics, politics and problematizations. An interview with Michel Foucault by Paul Rabinow in May 1984. In P. Rabinow (Ed.), Ethics. Subjectivity and truth. The essential works of Michel Foucault, 1954-1984 (pp. 111-119). New York: The New Press.

Google Chrome. (2014). Chromecast: How to mirror your Android phone or tablet to the TV. Retrieved from https://www.youtube.com/watch?v=s97h5rphp24

Graham, E. (n.d.). Using Smartphones in the classroom. NEA. Retrieved from http://www.nea.org//tools/ 56274.htm

Greer, C. F., \& Ferguson, D. A. (2015). Tablet computers and traditional television (TV) viewing Is the iPad replacing TV? Convergence: The International Journal of Research into New Media Technologies, 21(2), 244-256. doi:10.1177/1354856514541928

Grove, A. S. (1996, November 18). Intel keynote transcript-Comdex fall '96. Retrieved from http://www. intel.com/pressroom/archive/speeches/ag111896. htm

Hartley, J. (1999). Uses of television. London: Routledge.

Hassoun, D. (2012). Costly attentions: Governing the media multitasker. Continuum, 26(4), 653-664. doi:10.1080/10304312.2012.698041

Hassoun, D. (2014). Tracing attentions toward an analysis of simultaneous media use. Television \& New Media, 15(4), 271-288. doi:10.1177/1527476412468621 
Hassoun, D. (2015). "All over the place": A case study of classroom multitasking and attentional performance. New Media \& Society, 17(10), 1680-1695. doi:1461 444814531756

Hassoun, D. (2016). Engaging distractions: Regulating second screen use in the theater. Cinema Journal, 55(2), 89-111.

Hayles, K. (2012). Tech-TOC: Complex temporalities in living and technical beings. Electronic Book Review. Retrieved from http://www.electronicbookreview. com/thread/fictionspresent/inspective

Hediger, V., \& Vonderau, P. (Eds.). (2009). Films that work: Industrial film and the productivity of media. Amsterdam: Amsterdam University Press.

Hill, A. (2002). Big brother: The real audience. Television \& New Media, 3(3).

Jenkins, H. (2010). Transmedia storytelling and entertainment: An annotated syllabus. Continuum, 24(6), 943-958. doi:10.1080/10304312.2010.510599

Jenkins, H., Ford, S., \& Green, J. (2013). Spreadable media creating value and meaning in a networked culture. New York: New York University Press.

KeepYourEyesontheRoad.org.au. (n.d.). Retrieved May 3, 2016, from http://www.keepyoureyesontheroad. org.au

Keilbach, J., \& Stauff, M. (2013). When old media never stopped being new. Television's history as an ongoing experiment. In J. Teurlings \& M. de Valck (Eds.), After the break. Television theory today (pp. 79-98). Amsterdam: Amsterdam University Press.

Kelly, D. (2013, November 18). What is a learning ecosystem? Retrieved from http://twist.elearning guild.net/2013/11/what-is-a-learning-ecosystem

Kozinn, A. (2014, January 7). Distracted diva: The second screen goes to the opera. New York Times. Retrieved from http://artsbeat.blogs.nytimes.com/2014/07/01 /distracted-diva-the-secondscreen-goes-to-theopera

Lacey, K. (2013). Listening publics: The politics and experience of listening in the media age/Kate Lacey. Cambridge, UK: Polity Press.

Langlois, G. (2012). Participatory culture and the new governance of communication: The paradox of participatory media. Television \& New Media. doi:10.1177/1527476411433519

Lawler, R. (2013, November 9). Disney's second screen live asks moviegoers to bring their iPad this time (video). Engadget. Retrieved from http://www. engadget.com/2013/09/11/disney-second screenlive-ipad-theater-little-mermaid

Lee, H. J., \& Andrejevic, M. (2014). Second screen theory: From the democratic surround to the digital enclosure. In J. Holt \& K. Sanson (Eds.), Connected viewing: Selling, streaming, \& sharing media in the digital era. New York: Routledge.

Lintelus. (2014). Lintelus meeting: Engage your audience. Retrieved from https://www.youtube.com/watch
?v=rnwb-AMO5j8

Löffler, P. (2013). Bodies of distraction. In B. M. Pirani \& T. S. Smith (Eds.), Body and time: Bodily rhythms and social synchronism in the digital media society (pp. 820). Newcastle upon Tyne: Cambridge Scholars Publishing.

Löffler, P. (2014). Verteilte Aufmerksamkeit: Eine Mediengeschichte der Zerstreuung. Zürich: Diaphanes.

Manjoo, F. (2009, January 14). Want to get more work done? Try a Bigger screen. The New York Times. Retrieved from http://www.nytimes.com/2009/01/ 15/technology/personaltech/15basics.html

McCarthy, J. F., \& boyd, d. m. (2005). Digital backchannels in shared physical spaces: Experiences at an academic conference ( $\mathrm{CHI}$ '05 Extended Abstracts on Human Factors in Computing Systems). New York: ACM. doi:10.1145/1056808.1056986

Miller, J.-A. (1977). Suture (elements of the logic of the signifier). Screen, 18, 24-34.

Modleski, T. (1983). The rhythms of reception: Daytime television and women's work. In E. A. Kaplan (Ed.), Regarding television: Critical approaches-An anthology (pp. 67-75). Los Angeles: American Film Institute.

Monitor Jeugd en Media 2015. (2015, June 23). Retrieved May 3, 2016, from http://www.mediawijzer. net/monitor-jeugd-en-media-2015-grote-verschillenin-mediagebruik-tussen-jongeren-per-leeftijdonderwijsniveau-en-geslacht/

Morozov, E. (2011). The net delusion: The dark side of internet freedom (1st ed.). New York: Public Affairs.

Muir, S. A. (2012). The gloss and the reality of teaching digital natives: Taking the long view. In S. P. Ferris (Ed.), Teaching, learning and the Net generation: Concepts and tools for reaching digital learners (pp. 19-40). Retrieved from http://services.igi-global. com/resolvedoi/resolve.aspx?doi=10.4018/978-161350-347-8

mycommercials. (2007). Panasonic Hi-Fi VCR commercial (1986). Retrieved from https://www.youtube.com/ watch?v=h8WGAQYY-xQ

Nee, R. C., \& Dozier, D. M. (2015). Second screen effects. Linking multiscreen media use to television engagement and incidental learning. Convergence: The International Journal of Research into New Media Technologies. doi:10.1177/1354856515592510

Nielsen, L., \& Webb, W. (2011). Teaching generation text: Using cell phones to enhance learning. NJ: John Wiley \& Sons.

Pape, T. (2014). Preemptive narratives, modes of attention, and the politics of perception. Spectator, 34(2), 63-72.

Penenberg, A. L. (2013). Play at work: How games inspire breakthrough thinking. UK: Hachette Book Group.

Peters, J. D. (2005). Media as conversation, conversation 
as media. In J. Curran \& D. Morley (Eds.), Media and cultural theory (pp. 115-126). UK: Routledge.

Pettman, D. (2016). Infinite distraction: Paying attention to social media. Malden, MA: Polity.

Pittman, M., \& Tefertiller, A. C. (2015). With or without you: Connected viewing and co-viewing Twitter activity for traditional appointment and asynchronous broadcast television models. First Monday, 20(7). Retrieved from http://firstmonday.org/ojs/index.php/ $\mathrm{fm} /$ article/view/5935

Postman, N. (1986). Amusing ourselves to death. London: Penguin Books.

Read, J. (2014, December 18). Distracted by attention. Retrieved from http://thenewinquiry.com/essays/ distracted-by-attention

Rieger, S. (2012). Multitasking: Zur Ökonomie der Spaltung. Berlin: Suhrkamp.

Rizzo, T. (2015). Television assemblages. The Fibreculture Journal, (24). Retrieved from http://fibreculture journal.org/wp-content/pdfs/FC24_FullIssue.pdf\#pa ge $=88$

Selva, D. (2016). Social television audience and political engagement. Television \& New Media, 17(2), 159173.

Shirky, C. (2008, August 20). Gin, television, and cognitive surplus. Retrieved from https://edge.org/ conversation/clay_shirky-gin-television-andcognitive-surplus

Shirky, C. (2014, August 9). Why I just asked my students to put their laptops away. Retrieved from https://medium.com/@cshirky/why-i-just-asked-mystudents-to-put-their-laptops-away-7f5f7c50f368

Socrative. (n.d.). Socrative. Retrieved from http://www. socrative.com

Sørensen, I. E. (2016). The revival of live TV: Liveness in a multiplatform context. Media, Culture \& Society, 38(3), 381-399.

Stafford, B. M. (2009). Thoughts not our own: Whatever happened to selective attention? Theory, Culture \& Society, 26(2-3), 275-293.

Stauff, M. (2005). "Das neue Fernsehen". Machtanalyse, Gouvernementalität und digitale Medien. Münster: Lit-Verl.

Stauff, M. (2015). The second screen: Convergence as crisis. Zeitschrift für Medien- und Kulturforschung, 6(2), 123-144.

Struck, P. (2000, March 9). Wie die Persönlichkeit von
Kindern und Jugendlichen gestärkt werden kann. Retrieved from http://www.tagesspiegel.de/welt spiegel/gesundheit/wie-die-persoenlichkeit-vonkindern-und-jugendlichen-gestaerkt-werdenkann/128236.html

Terranova, T. (2012). Attention, economy and the brain. Culture Machine, 13. Retrieved from http://www. culturemachine.net/index.php/cm/article/viewDown loadInterstitial/465/484

Tussey, E. (2014). Connected viewing on the second screen: The limitations of the living room. In J. Holt \& K. Sanson (Eds.), Connected viewing: Selling, streaming, \& sharing media in the digital era (pp. 202-216). New York: Routledge.

van Es, K. (2015). The perks and perils of social TV: On the participation dilemma in NBCs The Voice. Television \& New Media. doi:10.1177/1527476415616191

Walsh, K. (2014). What does twitter really offer TV audiences, and at what cost? Spectator, 34(2), 11-15.

Weimer, M. (2012, September 26). Students think they can multitask. Here's proof they can't. Retrieved from http://www.facultyfocus.com/articles/teaching -professor-blog/multitasking-confronting-studentswith-the-facts

Weltevrede, E., Helmond, A., \& Gerlitz, C. (2014). The politics of real-time: A device perspective on social media platforms and search engines. Theory, Culture \& Society, 31(6), 125-150.

White, M. (2004). The attractions of television. Reconsidering liveness. In N. Couldry \& A. McCarthy (Eds.), MediaSpace: Place, scale and culture in a media age (pp. 75-92). London: Routledge.

Williams, R. (1990). Television. Technology and Cultural Form. London/New York: Routledge.

Wilson, S. (2016). In the living room second screens and TV audiences. Television \& New Media, 17(2), 174191.

Yardi, S. (2006). The role of the backchannel in collaborative learning environments (Proceedings of the 7th International Conference on Learning Sciences). Bloomington, Indiana: International Society of the Learning Sciences. Retrieved from http://dl.acm. org/citation.cfm?id=1150034.1150158

Ytreberg, E. (2009). Extended liveness and eventfulness in multi-platform reality formats. New Media \& Society, 11(4), 467-485.

\section{About the Author}

\section{Dr. Markus Stauff}

Markus Stauff teaches Media Studies at the University of Amsterdam (UvA). His main research interests are television and digital media, governmentality, visual culture of media sports. Recent publications: Transparency (special issue of Cultural Studies/Critical Methodologies 1/2014, edited together with J. Teurlings; "The Accountability of Performance in Media Sports: Slow-Motion Replay, the 'Phantom Punch', and the Mediated Body." Body Politics (2014): http://bodypolitics.de/de/wp-content/uploads/2015/07/Heft_3_06_Stauff_Performance_In_Media_Sports_End.pdf 